\title{
Csikós Júlia*
}

\section{RÁDAY ESZTER KÖNYVTÁRA}

\author{
Kulcsszavak: művelődéstörténet, könyvtártörténet, könyvtörténet, Régi Magyar Könyvtár
}

1859-ben, a sepsiszentgyörgyi Református Székely Mikó Kollégium alapításának évében, tanodai főgondnokká választották hidvégi gr. Mikó Imrét - az Erdélyi Református Egyházkerület főgondnokát -, széki gr. Teleki Domokost - az Erdélyi Református Egyházkerület államgondnokát - és lécfalvi Gyárfás Miklóst - a Rikánbelöli Kommunitás ${ }^{1}$ és a Sepsi Egyházmegye fógondnokát. ${ }^{2}$ Gr. Teleki Domokos 1860. április 1-jén kelt, az iskola elöljáróságához intézett levelében egészségi állapotára és elfoglaltságára hivatkozva visszautasította a megtiszteltetést. Levele így folytatódik: Ezennel azt kivánom a Tiszt. Egyház Közönséggel (Rikánbelöli Kommunitás) tudatni, miszerint több ezerre menó könyvtáramnak azon példányait, melyek az Erdélyi Múzeum Könyvtárában hijánoznának, az irt Intézetnek igértem. Könyvtáram többi részét ezennel egész készséggel ajánlom fel a Sepsi-Szent-Györgyi tanoda Könyvtára számára. $^{3}$

A könyvtár, melyet gr. Teleki Domokos (1810-1876) Gernyeszegen gyüjtött és használt - a fennmaradt katalógus szerint - mintegy 5500 kötet könyvet és 230 kötet bekötött folyóiratot tartalmazott. A hagyaték 1876-ban került a Református Székely Mikó Kollégium tulajdonába, természetesen azon kötetek nélkül, melyeket az Erdélyi Múzeum Könyvtára számára már korábban kiválasztottak. ${ }^{4}$ A Catalogus Librorum in Ill. Bibliotheca Gernyeszegensi Contentorum 1854 is a Mikó Kollégiumba került, a katalógus nyolc szak szerint csoportosítja a gyüjteményt: Biblioteca Auctorum veterum Graecorum et Latinorum - 414 kötet; Bibliotheca Theologica - 826 kötet; Bibliotheca Juridico Politica - 579 kötet; Bibliotheca

* Csıkós Júlia (1961, Sepsiszentgyörgy): Foglalkozás: könyvtáros, Székely Mikó Kollégium, Sepsiszentgyörgy, Néhány publikáció: Csı ós Júlia: Egy újabb kötet Apáczai Csere János könyvtárából = Örökség és feladat. Tanulmányok romániai magyar könyvekröl, könyvtárakról. Szerk. KISS Jenő. Sepsiszentgyörgy 1995. 58-62, Csı kós Júlia: Ráday Pál könyvei a Székely Mikó Kollégiumban. = Örökség és feladat. Tanulmányok romániai magyar könyvekröl, könyvtárakról. Szerk. KISS Jenő. Sepsiszentgyörgy 1995.63-69, Csiкós Júlia: A könyvtár öre. Erdélyi iskolák jeles könyvtárairól és könyvtárosairól. = Könyv és Nevelés 1999/2. 125-132. Csı Kósné PÉTER Júlia: A Székely Mikó Kollégium könyvgyújteményei. = Emlékkönyv a Székely Mikó Kollégium alapitásának jubileumára. Szerk. ÅrvaY Katalin és Dов RA Judit. Sepsiszentgyörgy 2009.32-57. E-mail: csikosjulia@gmail.com

1 A Rikánbelöli Kommunitás a sepsi-, kézdi-, orbai és miklósvárszéki protestáns egyházközségek lelkészeinek autonóm közgyúlése, köztörvényszéke.

2 Demeter Béla: Az elóljáróság tagjai 1859-1909. = A sepsiszentgyörgyi Református Székely Mikó Kollégium ötvenedik évi Értesitöjje 1908/1909. Szerk. PÉTER Mózes. Sepsiszentgyörgy, 1909. 82.

3 Az Állami Levéltár Kovászna megyei fiókja, Fond 171. - I. csomó, Levelezés 1856-1864. 73-74.

4 Bodor Domokos szerk.: A sepsi-szentgyörgyi evang. reform. Székely-Mikó Tanoda Értesitóje az 1880/81. iskolai évröl . Sepsiszentgyörgy, 1881. 37. 
Philosophica - 580 kötet; Bibliotheca Philologica - 956 kötet; Bibliotheca Antiquaria - 73 kötet; Bibliotheca Historica - 1136 kötet; Scriptores Rerum Hungaricarum et Transilvanicarum - 802 kötet. ${ }^{5}$ A könyvtárteremben szakok szerint állhattak a könyvek a polcokon, mert a kötetek gerincére ráragasztották a számot, amely a katalógusban szerepel, helyrajzi számként, de azt, hogy hányas szakhoz tartozik, csak később (más kézírással) írták be ceruzával a kötetek első előzéklapjára. A gerincen szereplő szám ugyanattól a kéztől származik, mint a katalógus. Gróf Teleki Domokos titkára 1848-1853 között Gyulai Pál volt, a katalóguson az 1854-es évszám áll, ez az a katalógus tehát, mely Gyulai Pál rendszerezésének az eredménye, de vannak benne pótlások más kézírással is.

Arról, hogy milyen jelentősége volt a gernyeszegi kastélyi könyvtárnak a 19. század első harmadában, szemléletesen tanúskodik Bolyai Farkas autográf ajánlása Tentamen c. művében, ahol munkáját nem személynek, hanem a Gernyeszegi Bibliothecának ajánlja. ${ }^{6}$ A könyvtárat - a possessor-bejegyzések alapján - gr. Teleki III. Domokos felmenői gyüjtötték; szülei: gr. Teleki III. József és gr. Teleki Zsófia, nagyszülei: gr. Teleki II. József és Róth Johanna, dédszülei: gr. Teleki II. László és Ráday Eszter, de a család korábban élt tagjai is: gr. Teleki I. Sándor, gr. Teleki II. Mihály. ${ }^{7}$

A sepsiszentgyörgyi Székely Mikó Kollégium Nagykönyvtárának számítógépes feldolgozása után megállapíthatjuk, hogy a gernyeszegi katalógusban szereplő könyvek mintegy hetvenöt százaléka az iskola tulajdonába került, a kolozsvári Egyetemi Könyvtárban őrzött könyvekről még csak ez a részleges összevetés készült el, amely során igyekeztünk Ráday Eszter gyüjteményének darabjait megtalálni.

Gr. Teleki Lászlóné Ráday Eszter (1716-1764) nevét a művelődéstörténetben, ezen belül a könyvkiadás patronálása és a könyvgyüjtés területén először Bod Péter tette ismertté, akivel személyes kapcsolatban állt. Bod Péter Önéletírásában, A magamtól íratott és nyomtatott könyvekröl c. felsorolásban pontosan feljegyezte, hogy munkájában kik és mivel támogatták. ${ }^{8}$

A Szent Bibliának Históriája második kiadását gr. Teleki László 54 magyar forinttal támogatta. „Másodszor 1756-dik esztendöben nyomtattattam ezen könyvecskét. Ezer exemplárért fizettem a könyvnyomtatónak fh. 229. Ebböl fizetett le a méltóságos gróf úr, Teleki László úr önagysága fh. 54". ${ }^{9}$ Gróf Teleki László és Ráday Eszter 50 magyar forinttal segítette $A$ Júdás apostol levele magyarázatának megjelenését. "Judás Apostol levele magyarázatját nyomtattattam ki Szebenben 1749. esztendöben. 600. exemplárokért fizettem fh. 204. Dedicálván méltóságos grófTeleki László úr ónagyságának és a méltóságos gróf asszony Rádai Eszter asszonynak, ajándékoztak önagyságok akkor fh. 50”. ${ }^{10} \mathrm{E}$ munkáját Bod Péter gr. Teleki Lászlónak és Ráday Eszternek ajánlotta tehát, mint Nékem jó és nagy Pátronus Uramnak és Pátrona Aszszonyomnak Ö Nagyságoknak, ugyanakkor háláját akarta kifejezni ezzel az ajánlással: „Légyen azért ez az én Nagyság-

5 A Székely Mikó Kollégium Nagykönyvtára, jelzet: Mss 335, Mss 336.

6 Csikósné PÉTer Júlia: A Székely Mikó Kollégium könyvgyüjteményei = Emlékkönyv a Székely Mikó Kollégium alapitásának jubileumára. Szerk. Árvay Katalin és Dobra Judit. Sepsiszentgyörgy, 2009. 48.

7 Nagy Iván: Magyarország családai czimerekkel és nemzedékrendi táblákkal. Pest 1865, XI. k. 82; 89.

8 Bod Péter Önéletírása. Bev. Egyed Emese. Marosvásárhely 2007. 131-135.

9 Uo. 131.

10 Uo 131. 
tokhoz való Háládatosságomnak tanúbizonysága a mig ez az Irás meg marad; meg marad pedig ez hoszszu idökre". ${ }^{11}$ A Synopsis Iuris Connubialis megjelenését Ráday Eszter 12 hollandiai aranynyal segítette. „Kezdettem nyomtattatni Szebenben 1763-dik esztendöben Synopsis Iuris Connubialist. Hatszáz exemplárt ád a könyonyomtató, melyért fizettem fh. 110. Ennek alkalmatosságával gróf Bethlen Imre úr önagysága adott két belga aranyakat, melyek tésznek fh. 9 den. 95. Méltóságos gróf Rádai Ester asszony, Teleki Lászlóné asszony ónagysága a fontatásának, szóteséinek baszna zsengéjéból adott 12 hollandiai aranyakat, melyek tésznek bijjánosok lévén... ". ${ }^{12}$ A Smirnai Szent Polikárpust Enyeden nyomtatták 1766-ban. Ráday Eszter már két évvel korábban meghalt, de végakarata szerint férje, gr. Teleki László 217 magyar forinttal támogatta a kötet megjelenését. „Nyomtattattam 1766-dik esztendöben Enyeden Sz. Polikárpust. Ezer exemplárt, árkosát fel portziájával fizetvén, mégyen fh. 225. [...] Küldött kezembe a méltóságos gróf Teleki László úr ennek nyomtatására $217 \mathrm{~m}$. forintokat, melyekról adtam ilyen recognitiot”. ${ }^{13}$ Bod Péter ezt úgy hálálta meg, hogy két leányuknak, Torotzkai Zsigmondné Teleki Eszternek és Teleki Klárának ajánlotta a könyvet. Az ajánlásban Ráday Esztert idézi, aki istenfélő asszony volt, háza népének szent tanításokat tartott. Ugyanakkor megemlíti Bod Péter, hogy a nemesaszszony mindig segítette a könyvkiadást és a könyvek beszerzésénél sem kímélt sem fáradtságot, sem pénzt és így „egy ritka szép Magyar Bibliotékát” gyưjtött össze, „hogy azokból a dolgokat kitanúlván, magát gyönyörködtesse s másoknak használjon" ${ }^{14}$

A kutatás igazi célja az volt, hogy minél több kötetet találjunk meg Ráday Eszter, a könygyưjtő és könyvkiadást patronáló nemesasszony könyvtárából. A könyvgyűjteménye jegyzékét Málnási László lelkész készítette el 1757-ben Gernyeszegen, ma a marosvásárhelyi Teleki Tékában a Thgy-95. Ms. 357. jelzeten őrzik. Ezúton szeretnék köszönetet mondani a Téka munkatársainak, hogy rendelkezésemre bocsátották a jegyzék másolatát, illetve Kolumbán Juditnak, a kolozsvári Egyetemi Könyvtár könyvtárosának, hogy nemcsak helyben, hanem később, a tisztázatlan esetekben levélben is segítségemre volt a kötetek ottani felkutatásában. A Székely Mikó Kollégium könyvtárában található kötetek azonosítása egy időben történt a számítógépes katalógus építésével.

Jakó Zsigmond 1976-ban megjelent tanulmányában megállapította: elsősorban Bod Péter hatásának tulajdonítható, hogy Árva Bethlen Kata környezetében egy bibliofil csoport jött létre főrangú asszonyokból. Ebbe a csoportba sorolja Bethlen Imréné Gyulai Klárát, Korda Zsigmondné Nemes Júliát, Nemes Juditot és Teleki Lászlóné Ráday Esztert. ${ }^{15}$ Bod Péter Bethlen Kata udvari papjaként - a lelki gondozás mellett gyarapította, rendszerezte és természetesen használta patrónája könyvtárát. Könyvjegyzéket is készített Bethlen Kata könyvtáráról, mely a Málnási László által készített jegyzékkel együtt teljes képet ad gyűjtője érdeklődési köréről ${ }^{16}$. Ugyanakkor Bod Péter munkáiban is többször megemlíti Bethlen Kata könyv-

11 Bod Péter: Szent Judas Lebbeus Apostol Levelének rövid Tanitásokban foglalt Magyarázatja. Szebenben 1749.

12 Bod Péter Önéletírása. Bev. Egyed Emese. Marosvásárhely, 2007.133.

13 Uo. 134.

14 Bod Péter: Smirnai Szent Polikárpus. [H. n., é. n.].

15 Jakó Zsigmond: A Székelyudvarhelyi Tudományos Könyvtár története. = Uő: Írás, könyv, értelmiség. Bukarest, 1976. 223.

16 Szabó Ágnes: Bethlen Kata és könyvtára = Simon Melinda - Sz. Á.: Betblen Kata könyvtárának rekonstrukciója (A Kárpát-medence koraújkori könyvtárai II.). Szeged, 1997. 
gyüjteményét, a Magyar Athenas szócikkében „igen szép Magyar Bibliotékát” említ. „Tudományokat igen szeretó nagy kegyességü tudós Uri Aszszony. Ez igen szép Magyar Bibliótékát állitott vólt fel magának, minden-felöl egybe-szedetvén oda Erdélyböl és Magyar országból a jó Magyar könyveket; mellyet még életében által-adott a N. Enyedi Kollégyiom könyves-Házába". ${ }^{17}$

Bethlen Katához nagyon közel állt lélekben gr. Teleki Lászlóné Ráday Eszter, akit ugyancsak 18. századi asszonykönyvtár gyưjtőjeként tart számon az utókor. Házasságaik révén rokoni kapcsolatba kerültek: Bethlen Kata második férje gr. Teleki I. József volt, kinek unokaöccse gr. Teleki II. László, Ráday Eszter férje. A találkozásuk Ráday Eszter férjhez menetele, 1732 után történt, de Teleki Lászlóné már korábban, a szülői házban megismerte és megszerette a könyveket.

Ráday Eszter 1716-ban született Losoncon, szülei, Ráday Pál és Kajali Klára második gyermekeként. Bátyja Ráday Gedeon költő, müfordító, irodalomszervező, politikus. Szüleik halála után, 1741-ben gr. Teleki Lászlóné és fiútestvérei megosztoztak az örökségen, a családi könyvtárat is elosztották. A Ráday Levéltárban fennmaradt jegyzék szerint Ráday Eszter 113 magyar nyelvű kötetet örökölt, testvérei főleg a latin nyelvüeket kapták ${ }^{18}$.

Az édesapa, Ráday Pál, II. Rákóczi Ferenc kancellárja életével és munkásságával foglalkozó irodalom nagyon sokrétű, hiszen a kuruc szabadságharcban betöltött szerepe, egyháza iránti feltétlen tisztelete, családja iránti szeretete, könyvgyưjtői szenvedélye közismert és legendás. ${ }^{19}$ Családjában nem ő volt az első könyvgyüjtő, édesapja, Ráday Gáspár megörökölte felmenői könyveinek felét, másik felét testvére, András kapta. Hogy mekkora lehetett ez a könyvtár, nem tudjuk, csak azt, hogy Ráday Gáspár az 1650-es birtokösszeíráskor könyveket is említ. Az viszont tény, hogy Debreczeni Ember Pál Garizim és Ébál c. könyvét ajándékba kapta a szerzőtől ${ }^{20}$, és Csúzi Cseh Jakab két munkáját előbb fia, Pál örökölte tőle, majd az ő lánya, Eszter, aki révén a Teleki-családba és onnan az Erdélyi Múzeum Könyvtárába került. (Csuzi Cseh Jakab: Lelki Bölcseségre Tanito Oskola. Debreczenben, 1680. jelzet: BMV 7122; Csuzi Cseh Jakab: Kincses Tar-haz. Sárospatak, 1668. jelzet: BMV 3590)

Ráday Pál egyik életrajzírója, Négyesy László megjegyzi, hogy míg Gedeon erélytelen és szelíd volt, addig Eszter örökölte édesapjuk „erélyét” és vallásosságát, a tudományszeretetét mindketten örökölték. Eszter már a szülői házban megismerte a katekizmust és a szentírást, Szent Pál leveleit szó szerint tudta idézni. ${ }^{21}$

Ráday Pál könyvtárát Borvölgyi Györgyi rekonstruálta, felhasználva munkájában e sorok írójának 1995-ben megjelent tanulmányát is, mely a sepsiszentgyörgyi Székely Mikó Kollégiumban található 11 kötetet azonosítja possessor-bejegyzés alapján. ${ }^{22}$ Az azóta eltelt idő alatt még sikerült két kötetet találni a Kollégium könyvtárában, melyekben benne van Ráday Pál posessor-bejegyzése, illetve idővel kapcsolatot teremteni a gerincen levő G.R.E. [Gróf Rádai Ester] monogram és a „Rádai Esteré”, illetve „Ex Libris Pauli Ráday [m.p.]” bejegyzé-

17 Bod Péter: Magyar Athenas. [H. n.]. 1766. 42.

18 Bonvölgyi Györgyi: Ráday Pál (1677-1733) könyvtára. Bp. 2004. 17.

19 Uo. 254-259.

20 Uo. 158-159.

21 Rádai Ráday Pál munkái. Összegyưjtötte és életrajzzal bevezette NÉGyesy László. Budapest, 1889. 37-38.

22 BorvöLGY Györgyi: i.m. 188-192. 
sek között. Borvölgyi Györgyi 2004-ben megjelent munkája késztetett a további kutatásra, mert Ráday Pál könyveinek számbavételénél többször említi, hogy mivel nincs meg az illető példány a Ráday Gyüjteményben, valószínű Eszter vitte magával Erdélybe, ahogy könyvjegyzékéből kitűnik. Kolozsváron az Erdélyi Múzeum Könyvtárában végzett kutatás azt az eredményt mutatja, hogy ott 24 kötet címlapján szerepel Ráday Pál posessor-bejegyzése, tehát összesen 37 kötetről állapítható meg biztonsággal, hogy Ráday Eszter édesapja könyvei közül örökölte és magával hozta Gernyeszegre. Czeglédi István két munkája közül, melyek címlapján szerepel Ráday Pál posessor-bejegyzése, ma egyiket Sepsiszentgyörgyön, másikat Kolozsváron őrzik. (Czeglédi István: Az orszagok romlasarul irot könyvnek Első Resze. Cassan, 1659. jelzet: 39; Czeglédi István: Siralmas szarándoki járásbol, csak nem régen haza érkezet Malach doktornak... Sárospatak, 1659. jelzet: BMV 3257).

Az édesanya Kajali Klára, Kajali Pálnak a lánya, aki „igen nagy rá termett bölcs státiszta és törvény tudó úr volt, és ugyan azért azon boldogtalan és szomoru kurucz motusokban egyik volt az 24 senatorok közül”, tehát a konföderált Magyarország szenátora, a kuruc hadsereg országos főhadbírája lett. ${ }^{23}$ Kajali Pálnak az egyház és a könyvek iránti tiszteletét példázza a tény, hogy Debreczeni Ember Pál Innepi ajándékul az Isten sátorába felvitetett siklusnak c. munkája elöljáró beszédében említi, hogy Kajali adományt tett „más keresztyén úri rendekkel’ a munka megjelenésére. $^{24}$

Kajali Pál lánya, Klára 1705-ben ment feleségül Ráday Pálhoz. Kajali Klára ${ }^{25}$ gyűjtötte a könyveket, szokása volt vásárolni, beszereztetni, Pekry Kata (Petrőczi Kata Szidónia leánya) is kérte, hogy számára is szerezzen be vallásos irodalmat magyar nyelven. Volt zsoltároskönyve, melybe bejegyzéseket tett, illetve tulajdonában volt Kegelius munkája, melyet Ráday Pál küldött meg neki. Az Erdélyi Múzeum Könyvtárában 4 kötetről állíthatjuk bizonyosan posessor-bejegyzés alapján -, hogy a Kajali Klára tulajdona volt és lánya, Eszter Erdélybe hozta, a Mikó Kollégiumba nem került ilyen kötet. (Meisner, Balthasar: Catholicus Valasz az Esaviták Eretnek kérdéseire. Francofurti, 1692. jelzet: BMV 8469; Pápai Páriz Ferenc: Pax Sepulcri. Kolosvaratt, 1698. jelzet: BMV 9417; Arndt, Johannes; Petrőczi Kata Sidonia, trad.: A Kereszt nehéz terhe alatt el-bágyatt sziveket élesztő jú illatú XII. Liliom. Kolosvaratt, 1705. jelzet: BMV 10578; Müller, Henrik; Szenczi Fekete István, trad.: Lelki nyugosztalo orak. Lőtsén, [é.n.]. jelzet: BMV 9836). Kegelius munkája, amelyről Beliczay Angéla említést tesz, és azt is megjegyzi, hogy Ráday Eszter könyvjegyzékében szerepel, 2 példányban van meg az Erdélyi Múzeum Könyvtárában, de egyiknek a címlapja és a kötése is hiányzik, a másikban nincs nyoma a szóban forgó tulajdonosoknak. Mivel Kajali Klára is, akárcsak férje a címlapra írta be posessor-bejegyzését, ez rekonstruálhatatlan, ugyanígy a Ráday Eszter monogramja a gerincen. Tanulmánya végkövetkeztetéseként Beliczay Angéla Kajali Klárát a kor két nagyasszonya, Petrőczi Kata Szidónia és Barkóczy Krisztina mellé állítja vallásossága, erkölcsi komolysága okán, mint jó feleség, anya és gazdasszony. ${ }^{26}$

23 Heckenast Gusztáv: Kajali Pál (Ráday Pál apósa) = Ráday Pál 1677-1733. Elóadások és tanulmányok születésének 300. érfordulójára. Szerk. Esze Tamás. Bp., 1980. 281.

24 Beliczay Angéla: Kajali Klára, Ráday Pál felesége = Ráday Pál 1677-1733. Elöadások és tanulmányok születésének 300. évfordulójára. Szerk. Esze Tamás. Bp., 1980. 159.

25 Uo.157-196.

26 Uo. 196. 
Erre nevelte leányát, Esztert is, akinek vallásossága és erkölcsi komolysága a könyvszeretetben is megmutatkozik, ugyanis a kor asszonyai főleg vallásos irodalmat gyüjtöttek és olvastak, amellett gazdasszonyi munkájukat segítő (állattenyésztéssel, növénytermesztéssel, kézimunkával foglalkozó) könyveket, illetve orvosi munkákat, melyek családjuk és teljes háznépük kezelésére, gyógyítására nyújtottak segítséget.

Intze István marosvásárhelyi prédikátor arról emlékezik Ráday Eszter temetésekor, hogy híre nemcsak Magyarországon, hanem Erdélyben is elterjedt, így szerezhetett róla tudomást gr. Teleki László is. ${ }^{27}$ Eszter nagy hírének oka a kor átlagán felüli múveltsége és gazdasszonyi tehetsége. Teleki Mihály, a család feje Szathmári Paksi Mihály marosvásárhelyi professzort kérte fel a leánykérésre. Érdekes momentum és abban a korban szokatlan, hogy szülei megfelelőnek találták a kérőt, de megkérdezték Esztert, és Ráday Pál akkor ígérte a választ, ha a fiatalok megismerkednek. ${ }^{28} \mathrm{Az}$ esküvőt 1732. június 24-én tartották Pécelen nagyszámú vendégsereg jelenlétében. A fiatal pár első otthona Huszton volt. Ráday Eszter első három gyermekét édesanyja házánál szülte, Pécelen. ${ }^{29}$ Tíz gyermeket szült: Dániel, László, Gedeon, Benjamin, Zsigmond és Krisztina gyermekkorban, Pál ifjú korában halt meg, felnőtt kort József, Eszter és Klára ért meg.

Málnási László lelkész is megemlékezik patrónája könyveiről a felette tartott halotti beszédben, ritka, szép nagy könyvtárát említi Ráday Eszternek. „Midőn sok Tudós Theológusoknak, Magyar Nyelvre forditatott, vagy Magyarul-is irott Könyveiket, nagy árron-is és buzgó szorgalmatoskodásai-által egybe-gyüjtögette, (: no hiszem, a kinek tetzik, meg-tekintheti e Háznál ma is az ö Magyar Thecaját, mellynek a két M. Hazákban, a nálamnál többet látott hallott emberek-is meg-vallyák, hogy vagy alig, vagy nits-is párja:)". ${ }^{30}$

A Teleki Tékában fennmaradt könyvjegyzékben 246 tétel, valójában 232 cím szerepel, ez a könyvtár abban a korban jelentős gyưjteménynek számított, ha figyelembe vesszük, hogy Bod Péternek 888, Pápai Páriz Ferencnek 300, Árva Bethlen Katának 442 kötete volt. Málnási László a halotti beszédet Nagyszebenben mondta el, gr. Teleki László „Gróf Ur Ö nagys. Szállása nagyobbik Palotáján”, tehát a könyvek gyưjteménye vagy annak egy része e Háznál, Szebenben állt.

Ráday Eszter ritkán írt possessor-bejegyzéseket könyveibe, ellenben monogramos kötésbe köttette, Bethlen Kata példája nyomán, ahogyan Bod Péter emlékezik patrónájára a felette tartott halotti beszédében:

Könyveit egy formán mind bé is köttette,

Nevét A. B. K.-ával sarkára jedzette, ${ }^{31}$

Az évek alatt végzett feltárás folyamán egyre több kötet került elő a Székely Mikó Kollégium Könyvtárában, melynek gerincén megtalálható Ráday Eszter monogramja. Ezt követte a Ráday Eszter könyvjegyzékének tanulmányozása, a sokszor zavart okozó rövidítések felol-

27 Intze István: Halotti Oratio...néhai méltos. Grof. Rádai Radai Esther Aszszony Ö Nagyságának. [H. n.] 1766.

28 Beliczay Angéla: i. m. 174-175.

29 Uo. 194.

30 Málnási László: Törvényböl valo Igazságot magátol el-hárito, evangeliomi Igazságot magának válasz to Igaz Ember. Kolosváratt, 1766.

31 Szabó Ágnes: i. m. XVI. 
dása (ez sajnos, nem minden esetben sikerült). A következő lépés volt, a kolozsvári Egyetemi Könyvtárban - mely intézmény az Erdélyi Múzeum Könyvtárát kezeli az államosítás után -, kézbe venni azokat a köteteket, melyek a Ráday Eszter könyvjegyzékében szerepelnek, hogy képet kaphassunk arról, Gernyeszegről mely kötetek kerültek oda gr. Teleki Domokos adománya révén.

A Ráday Eszter könyvei lelőhelyének kutatásakor kiderült, hogy a Kolozsvárra került kötetek gerincén nincs meg a gernyeszegi ragasztott helyrajzi szám, ez csak Sepsiszentgyörgyön maradt meg. Pontosan ezek a számok akadályozták a Ráday Pál könyveinek első számba vétele alkalmával (1995-ben), a Ráday Eszter monogramja és a possessor-bejegyzések közötti kapcsolat megteremtését. A helyrajzi számot jelző papírt nagyon sok esetben ráragasztották a G.R.E. monogramra, a Ráday Eszter könyvjegyzéke ismeretében ezeket le kellett áztatni, hogy esetleg előtűnjön a három betű.

A Székely Mikó Kollégium és az Erdélyi Múzeum Könyvtárában összesen 114 kötetről állapítható meg posessor-bejegyzések, a gerincen található monogram, illetve a gernyeszegi katalógusból egyértelmű következtés alapján, hogy a Ráday Eszter tulajdonában volt: ebből 57 Sepsiszentgyörgyön, 57 Kolozsváron található. Van olyan eset is, hogy Ráday Eszter tulajdonosi volta nem, csak a Ráday családtagoké világos, de az ő közvetítése nélkül nem kerülhettek volna Gernyeszegre a kötetek. Ami a kötetek nyelvét illeti, 1 német és 1 latin nyelvű kötet van a jegyzékben, a német nyelvű a kanárimadár tenyésztéséről szól (Hervieux: Neuer Tractat Von denen Canarien-Vögeln. Leipzig, 1730., a Székely Mikó Kollégium Könyvtárában, jelzet: 3766), a latin nyelvű orvostudományi munka, gyógyszerkönyv (Richter Christian Siegismund: Recensio Succinta de Usu et Effectis aliquot Medicamentorum Selectorum. Halae Magdeburgicae, 1720., a Székely Mikó Kollégium Könyvtárában, jelzet: 3790). A többi 230 kötet magyar nyelvü.

Málnási László a köteteket szerzők szerint, betűrendben sorolta fel, nincs tematikus felosztás. Ha elemezzük ezt a 232 kötetet, elmondhatjuk, hogy 141 RMK van köztük, 5 kéziratos könyv, 73 tétel 18. századi magyar könyv. 17 kötetet, sajnos, nem sikerült azonosítanom. 29 tudományos mú, 5 kötet szépirodalom, 197 kötet teológiai-vallásos irodalom szerepel a jegyzékben. A tudományos irodalom területén számottevő az orvostudományi munkák aránya, azonkívül történelmi tárgyú és növény- illetve állattenyésztéssel foglalkozó munkák szerepelnek. A szépirodalmat Balassi Bálint, Faludi Ferenc, Gyöngyösi István, Benitzky Péter és Zrínyi Miklós képviseli. A possessorokat illetően 37 volt korábban a Ráday Pál tulajdona, 2 a Ráday Gáspáré - és később a Pálé -, 1 a Ráday Gedeoné, valamint 4 kötet volt a Kajali Klára tulajdonában.

Amikor gr. Teleki Domokos a már említett jelentős adományt tette, úgy rendelkezett, hogy az Erdélyi Múzeum könyvtárának, jelesen Szabó Károly könyvtárőrnek előválogatási joga volt, és azok a kötetek kerültek a Mikó Kollégiumba, amelyek Kolozsváron már megvoltak. Így történhetett az is, hogy a Ráday Eszter könyvjegyzékében szereplő kötetek közül 7 esetben említi Szabó Károly az RMK-ban, hogy az Erdélyi Múzeum Könyvtárába gr. Teleki Domokos gernyeszegi könyvtárából került a tárgyalt munka, sőt 4 esetben mint egyetlen ismert példány. A négy könyvészeti ritkaság a következő: Enyedi Molnár János: Az Isten igeretinek fel-nyittatott Arany Bányája, Ráday Pál possessor-bejegyzésével, Ráday Eszter kötésében RMK I. 1027, jelzet: BMV 3727; Marosi István: Füge Fiszek, Ráday Eszter kötésében RMK I. 1129, jelzet: BMV 4503; Pázmány Péter: Egy Keresztien Predikatortul Az Cassai nevezetes tanitohoz Alvinczi Péter Uramboz, Ráday Eszter kötésében RMK I. 416, jelzet: BMV 
1420; Péczeli Király Imre Cathekizmusa, Ráday Pál possessor-bejegyzésével, Ráday Eszter kötésében RMK I. 653, jelzet: BMV 2013.

A marosvásárhelyi Teleki Tékában őrzött könyvjegyzék szerint számbavett köteteken kívül a sepsiszentgyörgyi Székely Mikó Kollégium Nagykönyvtárában még 12 kötet található, melyeket GRE monogramos kötésbe kötöttek. 8 kötet közülük a Ráday és Teleki család tagjai felett tartott halotti beszédeket tartalmazó kolligátum (jelzetek: 6277-6284). Melius Péter: Herbarium Az Faknac Fvveknec nevekröl. Colosuárat 1578. c múvének hiányzik a címlapja, a kötése ép (jelzet: 3). Bod Péter munkái közül 3 került a jegyzékbe, a negyedik a Szent Heortokrates. Oppenheim 1757 (jelzet: 6490), és a Mikó Kollégium Nagykönyvtárában van még GRE monogramos kötésben Soos Franciscus: Positiones de Peste. Claudiopoli 1720 (jelzet: 3136), valamint Drégely-Palánky János: Conciones in Catechism Palatinatam. Kassa 1667 (jelzet: 45).

Az Egyetemi Könyvtár különgyưjteményében kézbe vett kötetek közül 18-at újrakötöttek, vagy javították a kötését, 3 kötetnek sérült a gerince, ezen kötetek esetében nem állapítható meg a Ráday Eszter tulajdonosi volta.

Ez a néhány adalék rávilágít arra, hogy gr. Teleki Lászlóné Ráday Eszter, saját és férje családjának hagyományait követve, a kor neves könyvgyüjtő és könyvkiadást patronáló asszonyai között foglalt helyet. Ugyanakkor könyvei mintegy felének a mai lelőhelyét megtalálva látjuk, hogy példája családjában sem volt hiábavaló: dédunokája két jelentős erdélyi intézményt támogatott a több nemzedék alatt összegyưjtött könyvállománnyal.

\section{THE ESZTER RÁDAY'S LIBRARY}

\section{Keywords: cultural history, library history, book history, Old Hungarian Library}

Countess Teleki Lászlóné Ráday Eszter may be regarded as one of the outstanding bibliophiles of the $18^{\text {th }}$ century. The catalogue comprising the titles of her collection is safeguarded in the Teleki Téka, in Marosvásárhely.

The present paper attempts to offer an insight into her childhood and family life - her father, Ráday Pál being the chancellor during II. Rákóczi Ferenc's Principality - of those circumstances that may have triggered her love for books and greatly contributed to her later passion of collecting them.

At the same time, we may find out information about her relationship with Bod Peter and Árva Bethlen Kata, the other representative bibliophiles and collectors of the $18^{\text {th }}$ century.

Ráday Eszter's catalogue entails a total of 246 items, out of these 114 volumes were successfully retrieved from two major Transylvanian collections - one being at Székely Mikó Upper Secondary School and the other in the former library of the Transylvanian Museum Society (today known as the library of Babeş-Bolyai University). The books were all donated by her great-grandson, count Teleki Domokos (1810-1876). As well as these, we also attempt to render some data with regard to the current situation and placement of the books belonging to her father, Ráday Pál. 


\section{BIBLIOTECA LUI RÁDAY ESZTER}

\section{Cuvinte-cheie: istoria civilizației, istoria bibliotecii, istoria cărții, Biblioteca Maghiară Veche}

Ráday Eszter, soția contelui Teleki László este o colecționară de cărți din secolul al XVIII-lea, inventarul bibliotecii sale personale se păstrează în Biblioteca Teleki Téka din Târgu Mureș. Studiul de față își propune o prezentare a anturajului familial - tatăl fiind Ráday Pál, cancelarul domnitorului Rákóczi Ferenc al II-lea - un mediu în care Ráday Eszter a avut primul contact cu universul cărților, și-a format profilul de bibliofilă și deprinderile de colecționar. Lucrarea surprinde și aspecte ale legăturilor lui Ráday Eszter cu Bod Péter și Árva Bethlen Kata.

Inventarul colecției lui Ráday Eszter cuprinde 246 de poziții. Dintre aceste volume s-a reușit identificarea a 114 de cărți în cele două colecții transilvane importante: Biblioteca Colegiului Székely Mikó din Sfântu Gheorghe, respectiv Biblioteca Muzeului Transilvan Erdélyi Múzeum de la Cluj (aflată în prezent în posesia Bibliotecii Universității Babeș-Bolyai). Cărțile colecției Ráday au fost donate celor două instituții de către strănepotul lui Ráday Eszter, contele Teleki Domokos (1810-1876). Această trecere în revistă a elementelor colecției ne oferă totodată și repere pentru identificarea și localizarea cărților colecției aparținând tatălui ei, Ráday Pál. 